

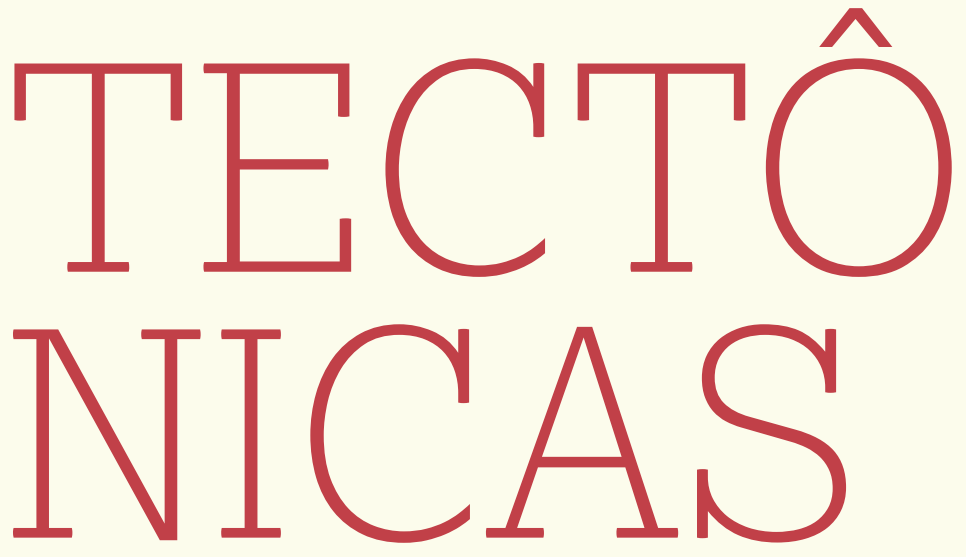

Do grego tektonikos, -ê,, -ón. Arte de carpinteiro. Arte de construir edifícios. Estudo da estrutura da crosta terrestre. Placas tectônicas, criadas nas zonas de divergência, seu afastamento possibilita a explosão do magma. 


\title{
O OLHO DO MELRO - BECKETT ENTRE O REALISMO DE LUKÁCS E A ESTÉTICA ADORNIANA
}

\author{
- FÁBIO SALEM DAIE
}

\section{RESUMO}

O presente artigo visa explorar alguns temas das perspectivas teóricas de György Lukács e Theodor Adorno relativas à arte no século XX. Para tanto, tomamos como ponto de partida três obras dramatúrgicas principais de Samuel Beckett: Esperando Godot (1953), Fim de Partida (1957) e Dias Felizes (1961). Visto que Beckett assumia valores inversos para Lukács e Adorno - desprezado pelo primeiro, admirado pelo segundo -, suas peças de teatro funcionam como catalisadoras de discordância centrais que nos ajudam a esclarecer parte relevante do debate estético moderno. Ao final, o que se deseja demonstrar é como categorias internas do conceito lukácsiano de "realismo" permanecem como dispositivos analíticos adequados para pensar a obra beckettiana.

Palavras-chave: Samuel Beckett, György Lukács, Theodor Adorno, realismo, modernismo.

\section{ABSTRACT}

The present article aims to explore some themes of György Lukács and Theodor Adorno's art theory related to the $20^{\text {th }}$ century. For this purpose, the starting point is three of Samuel Beckett's dramatic works: Waiting for Godot (1953), Endgame (1957) and Happy Days (1961). Since Beckett has received reversed values from Lukács and Adornodespised by the first, admired by the second -, his theater plays have a catalytic role to central discrepancies that help us to clarify an important part of the modern esthetic debate. At the end, what we wish to demonstrate is how internal categories from Lukács' concept of "realism" remain analytical devices proper to think Samuel Beckett's work.

Keywords: Samuel Beckett, György Lukács, Theodor Adorno, realism, modernism.

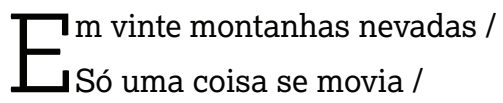

O olho do melro.

(STEVEns, acessado em 2015). 
Este texto tem a intenção de buscar uma linha, ainda que tênue, na qual convergem categorias e conceitos de dois grandes teóricos da Estética do século vinte: Theodor Adorno e György Lukács. Para tanto, pareceu propícia a abordagem de algumas peças importantes do irlandês Samuel Beckett ${ }^{1}$, visto contar este com a grande admiração do filósofo alemão e, como contraparte e em igual medida, com o desapreço do teórico húngaro. Assim, o esforço constitui-se na tentativa, certamente lacunar em alguns momentos, de colocar frontalmente pontos importantes do pensamento de Adorno e Lukács por meio da escrita beckettiana, a fim de encontrar uma saída plausível para um impasse teórico. Trata-se do conhecido debate em torno do conceito de realismo, caro a Lukács e que Adorno sempre rejeitou, no contexto do século vinte, como opção estética anacrônica. Ainda segundo Adorno, seu manejo à luz de obras modernistas seria a prova do pensamento pouco dialético de Lukács, porque não atinente a pontos como a ascensão do "mundo administrado" e a "crise do sujeito burguês" (TERTUlian, 2010, p. 4). O "mundo administrado", realidade em que a indústria de massa passa a produzir não apenas mercadorias em série, mas as próprias necessidades do indivíduo, manipulando a demanda e eliminando a possibilidade de crítica exterior a seu modus operandi - daí seu caráter totalitário -, acaba por esvaziar, no processo de homogeneização de produtos e indivíduos, também a dimensão subjetiva do chamado sujeito moderno, marcado então pelo sinal de crise. Por isso, diz Adorno, "já não há espaço algum para o "indivíduo", cujas exigências - onde ainda eventualmente existirem - são ilusórias, ou seja, forçadas a se amoldarem aos padrões gerais" (Adorno, 1980, p. 170). Responsáveis pelo isolamento social da vanguarda artística ("isolamento" e "vanguarda" são, neste contexto, quase sinônimos), a falência do sujeito e o mundo administrado implicam a queda da noção de "gosto", retirando a arte do seio dos julgamentos individuais amparados no esteio coletivo da tradição, e lançando-a ao confronto direto com o mundo pelo seu teor de verdade. Essa "Aufklaerung total", consequência do isolamento social, "converte-se num perigo mortal para a sua própria realização" (AdoRno, 2007, p. 23). Daí porque, tanto na teoria do realismo de Lukács (onde o posicionamento político tem primazia) quanto na teoria estética adorniana (na qual a noção de "gosto" foi destituída), o problema da perspectiva de mundo ganhar relevo especial.

O problema da perspectiva é tão grande que, infelizmente, torna-se impossível, nos limites deste trabalho, tratá-lo devidamente. Ele seria a continuação de tudo o que está argumentado aqui. Esquivando-nos de fazer um arrazoado desse debate - por todas as vias, extenso -, queremos unicamente apontar aquelas potencialidades latentes no conceito
[1] Para os fins deste trabalho, aborda-se apenas as obras Esperando Godot (1953), Fim de Partida (1957) e Dias Felizes (1961). 
lukácsiano de realismo. Mais especificamente, "latente" está em sua acepção latina original, como o que permanece "escondido", "encoberto" ou "oculto", a saber: serão exploradas as categorias internas do conceito, cujos desdobramentos, segundo acreditamos, podem auxiliar na compreensão do próprio realismo e de obras artísticas modernas. A riqueza e a astúcia de cada categoria deverão ser suficientes para trazer à tona uma pequena parte da contribuição de Lukács à teoria estética, marcando sua vigência. Dito isso, a primeira recordação é de que este conceito não corresponde a uma escola literária. Somente sob tal aspecto que, para Lukács, autores tão díspares como Goethe e Mann podem ser considerados grandes realistas, para além de suas filiações românticas, clássicas ou modernistas. Citando Karel Kosik, o professor Leandro Konder assim explica a amplitude da noção de realismo: "Toda concepção do realismo ou do não-realismo é baseada sobre uma consciente ou inconsciente concepção da realidade. O que seja o realismo ou o não-realismo em arte depende sempre do que é a realidade e de como se concebe a própria realidade" (KONDER, 2005, p. 73).

Obviamente, tal observação não deve levar a uma relatividade extrema, em que o próprio conceito se mostre completamente desfigurado e, portanto, inútil para fins da análise estética. O objetivo é somente apontar como o realismo se afirmaria em Beckett por meio de algumas de suas categorias internas (totalidade, tipicidade, ação), transformadas no seu contato direto com a obra. Reside aqui, nesta sugestão contra-intuitiva (Beckett como um realista moderno) a ideia inicial de que a grande discordância de Lukács sobre a obra beckettiana é uma discordância fundamentalmente de perspectiva ("concepção da realidade", como diz Konder), o que tornaria possível reconhecer, no interior das obras, essas categorias centrais do conceito de realismo, mesmo que o conjunto se mantenha, devido a sua configuração geral, como fonte de divergências.

Não há dúvida de que o lugar central que Beckett ocupa na Teoria Estética de Adorno se deve a uma concepção de realidade, em grande medida, compatível entre ambos. Essa concepção não é partilhada por Lukács e, em razão disso, muitas vezes se torna motivo de interpretações equivocadas no que concerne ao próprio conceito de realismo. Para que se tenha uma pequena noção do que envolve o problema da perspectiva ao se tentar equacionar a) a dramaturgia beckettiana, b) alguns aspectos da Estética adorniana e c) o conceito de realismo de Lukács, poder-se-ia mencionar o seguinte:

Adorno considerava plenamente plausível que grandes obras progressistas fossem escritas por autores reacionários: a objetividade das verdadeiras obras de arte, segundo ele, supera a subjetividade autoral, 
uma vez que ambos (obra e autor) estão inseridos em forças históricas que perfazem, inclusive inconscientemente, a sociedade. A esse respeito, existem críticos que tendem a negar ao pensamento de Lukács esse mesmo movimento de superação próprio à obra de arte, visto a marcante preocupação do filósofo húngaro com a concepção da realidade por parte do artista. Tais críticos buscam afirmar que Lukács preocupava-se demasiadamente com a perspectiva justamente por sustentar uma concepção mecânica entre as convicções do autor e a conformação final da obra. Assim, segundo essa interpretação do pensamento lukácsiano, uma grande obra só poderia ser concebida por um autor com a perspectiva de mundo correta. Tal leitura mostra-se, no entanto, equivocada. Um exemplo claro está em Realismo Crítico Hoje (1957-1958), onde Lukács trata abertamente do caráter progressista das obras de Heine e Dostoiévski, a despeito da perspectiva conservadora que ambos possuíam.

Dito isto, a verdadeira razão pela qual Lukács dedica parte de seus esforços intelectuais especificamente ao problema da perspectiva do artista é porque o filósofo marxista considerava que esta subjetividade ainda era (e, para ele, sempre será) um campo aberto à disputa ideológica. Nessa disputa, faz-se necessária a tomada de consciência contra todas as formas de decadência e apequenamento "pequeno-burguesas", que condenam a visão do artista a um pessimismo cuja saída (a superação do mundo burguês) lhe está vedada. Naturalmente, só poderia preocupar-se com este problema aquele que considerasse tal superação possível, não pelo stalinismo (outro argumento, também, equivocadamente mobilizado contra Lukács), mas pela existência, no interior de qualquer sociedade, de resistências e tensões constantes. Em outras palavras: pela existência da luta de classes. "O realismo" diz ele - "pressupõe a possibilidade - ou, pelo menos, a esperança - de uma vida que, mesmo no interior do mundo burguês, tenha um mínimo de significação; a arte de vanguarda suprime estas perspectivas" (LuKÁCS, 1969, p. 108). No mundo da "administração total", de Adorno, é natural que esta preocupação receba tons diferentes, e assim também o problema da perspectiva. Não mais redimido por um esforço coletivo em direção da superação do horizonte burguês, o isolamento social do artista (citado mais acima) traz desafios e desdobramentos suplementares, explorados pela teoria adorniana.

Ao esboçar brevemente essas falsas noções que resistem sobre o pensamento de Lukács, trata-se, agora, de mostrar (ou tentar mostrar) igualmente o conceito de realismo sob sua face dialética, e que só pode ser atualizadora dos conflitos históricos tais como aparecem no horizonte das sociedades. Isso corresponde a buscar a atualidade do realismo 
lukácsiano, ainda que tal tarefa signifique explorar os limites do seu alcance contra os propósitos do próprio crítico. O desafio é tentar levar o conceito a superar a si mesmo, tensionando-o a partir de categorias internas e contando, frequentemente, com o auxílio da Teoria Estética de Theodor Adorno.

\section{TOTALIDADE INTENSIVA E TOTALIDADE EXTENSIVA}

Talvez seja mais simples começar com o conceito de totalidade, visto que ele está presente de forma mais aparente em artigos importantes de Lukács como, por exemplo, "Narrar ou Descrever?". Nesse texto, o autor opõe a ideia de "totalidade" àquela de "fragmentariedade". Esta pode ser afiançada em excertos sobre o método descritivo, presente em obras de Zola e Flaubert: “(...) os acontecimentos se transformam, aos olhos dos leitores, em um quadro, ou melhor, em uma série de quadros" (LuKÁCS, 2010, p. 154). Ou ainda: "Os acontecimentos da corrida são apenas frouxamente ligados ao enredo e poderiam facilmente ser suprimidos, já que sua ligação com o todo consiste apenas no fato de que um dos muitos amantes passageiros de Naná se arruinou (...)" (LuKÁCS, idem, p. 149).

Por sua vez, ao tratar do método narrativo, Lukács diagnostica na cena da corrida de cavalos, em Anna Kariênina, de Tolstói, não "um 'quadro', mas uma série de cenas altamente dramáticas, que assinalam uma profunda mudança no conjunto do enredo"; bem como o fato de que "a queda de Vronski é a culminação de toda esta fase dramática da sua vida e, com ela, se interrompe a narração da corrida" (LuKÁcs, idem, p. 150). Está aí, contida nesses trechos, a noção de totalidade intensiva, como a define Konder em seu ensaio "Anotações sobre o Realismo":

\footnotetext{
A consciência busca certa visão do conjunto, mas as limitações que a prendem ao pseudoconcreto não lhe permitem enxergar as mediações, que são imprescindíveis à totalidade concreta. A totalidade concreta, por sua vez, não é extensiva; não pretende se compor de todos os atos; ela dá conta da estrutura significativa do todo tal como é estruturado pela práxis. É uma totalidade intensiva (KONDER, idem, p. 73).
}

Com isso, Konder busca teorizar um movimento que não se restringe às observações de Lukács sobre Anna Kariênina, mas que está, de uma maneira ou de outra, presente em todas as obras realistas e, mesmo, na vida real. O que se dá é o reconhecimento de que, em determinados pontos 
específicos de uma narrativa realista, é possível encontrar todas as relações que perpassam o livro do início até o final, onde a totalidade está presente de maneira intensa. O conceito aparece em seu livro Realismo Crítico Hoje, quando, ao defender a "exigência da onilateralidade" na visão sobre qualquer objeto, Lukács conclui: "É muito natural que, no plano literário - em que a totalidade intensiva deve prevalecer, com toda a evidência, sobre a extensiva - esta exigência seja, de direito, ainda mais imperiosa" (LuKÁcs, 1969, p. 146, itálico meu). Abordando a narrativa beckettiana, pode-se vislumbrar que esse mesmo conceito de totalidade está presente numa obra que não possui ponto específico algum - visto que não possui trama alguma -, e por isso, justamente, aparece em seu sinal negativo. Para tanto, vê-se necessário pensar a forma em seu sentido primeiro, de articulação das partes com o todo: se, em Tolstói, segundo Lukács, é possível perceber como todos os elementos da passagem específica da corrida de cavalos (e não, digamos, de outra passagem qualquer) já estão presentes tanto no início do romance quanto no final, em Beckett, tal intensidade parece assumir sua negação completa em uma totalidade extensiva, já que todos os momentos seriam, literalmente, mutuamente permutáveis. Não importa, por exemplo, em Fim de Partida, qual o momento específico em que Clov vê uma criança vindo pela praia. Ainda poder-se-ia argumentar que a aparição dessa criança, ao final, está carregada de "outro peso" cênico. É possível. Mas deve-se reparar aqui que um ocasional deslocamento do momento dessa passagem não ultrapassaria a surpresa (sem dúvida planejada por Beckett) de seu surgimento para uma implicação estrutural na obra. Nada exemplifica melhor essa característica da escrita beckettiana do que a passagem, contada em O Silêncio Possível, sobre um conto de Beckett publicado numa prestigiada revista francesa:

O quão anticlimáticas e insólitas eram essas histórias e a personagem que apresentavam pode-se aquilatar pela sorte editorial que amargou a primeira delas a ser publicada: "Suite", nome que tinha originalmente "La Fin" quando entregue à redação de Les Temps Modernes, saiu cortada pela metade, sem que os editores dessem pelo fato (ANDRADE, 2001, p. 20).

Seguindo o mesmo espírito, o significado da criança, no contexto de Fim de Partida (arrisca-se um: aquela que viria redimir do apocalipse os seres humanos), não mudaria essencialmente se sua aparição fosse transferida do fim para o início. Isso não significa, como pode parecer à primeira vista, que Beckett poderia, de acordo com esse raciocínio, muito bem ter escrito Fim de Partida de qualquer outro jeito. Justamente o 
contrário: significa, isto sim, que somente através da maneira exata como Beckett a escreveu, o episódio da criança pôde tornar-se extensivamente coerente à totalidade da obra. Esta liberdade apenas alcançada pelo rigor, na obra beckettiana, é tema na Teoria Estética de Adorno:

La objetivación pasa por los extremos. La necesidad de expresión que no ha sido domada ni por el gusto ni por el entendimiento artístico converge con la desnudez de la objetividad racional. (...). De esta racionalidad objetiva inmanente es en todo instante el arte de Beckett, aislado férreamente contra la racionalidad superficial (...), en la renuncia a aditamentos superfluos y, por tanto, irracionales (AdoRno, 2011, p. 158).

É interessante notar que Fábio de Souza Andrade, em seu estudo de Fim de Partida, tenha acusado como possibilidade para essa permutação mútua dos momentos da peça a imagem lukácsiana dos "quadros" peculiar do método descritivo, mais naturalista do que propriamente realista, para Lukács -, porém, dessa feita, relacionando-a, em Beckett, a uma totalidade:

Ao mesmo tempo, o teatro foi progressivamente perdendo sua característica maior, a apresentação de destinos em movimento, corporificados na ação, em nome de uma maior atenção às imagens acabadas, de caráter quase pictórico, quadros que pedem a contemplação em si, independentes do encadeamento e sucessão de episódios, descolando-se do processo para constituírem-se enquanto totalidades expressivas em si. Uma narrativa dramatizada, enovelada no moto contínuo da consciência, põe-se ao lado de um teatro imobilizado que, cada vez mais, abandona o legato dramático em nome do stacatto expressivo de quadros justapostos (ANDRADE, 2002, p. 26).

Andrade expõe o método de Beckett que permite, afinal, que o conceito de totalidade, em seu caráter extensivo, esteja presente nas obras teatrais mais aparentemente fragmentadas: a construção rigorosa dessa "racionalidad objetiva inmanente" (Adorno) que, ao compor a totalidade em cada momento do texto, permite que a cena da criança na praia seja coerente tanto no início quanto, digamos, no final. Igualmente, em Esperando Godot, não há, no primeiro ato, desenvolvimento algum que prepare a entrada de Pozzo e Lucky. Sua passagem é, sob o ponto de vista do conteúdo, tão arbitrária quanto a existência dos dois personagens centrais. Pese que o início in media res seja um procedimento comum em obras realistas, o distintivo em Beckett é isto: não há verdadeira media 
res, porque não há história, enredo ou trama. Em Esperando Godot, o peso do arbítrio está na constatação de que a entrada e a saída de Pozzo e Lucky não antecipam, desenvolvem ou finalizam coisa alguma - diferente, portanto, da obra realista.

Porém, sob a perspectiva da forma, fica claro que tal arbítrio não é, de maneira alguma, arbitrário, antes compondo uma intrincada conjugação de totalidades. Existe aqui a ideia - tão cara a Lukács quando se trata do realismo - de necessidade, em lugar do que seria simples casualidade, erguida pela sequencia de quadros da descrição naturalista. Tanto é assim que Hugh Kenner, crítico da peça em 1973, sublinha:

\begin{abstract}
Esperar pelo inevitável é espera de uma qualidade diversa, tanto que, não ocorresse a morte de Agamemnon, a peça daria a impressão de uma fraude. Mas não é uma fraude que Godot não venha. Esperar e fazer com que a platéia compartilhe a espera; e explicar a qualidade da espera: isto não se faz com um 'enredo', que converge para um evento cuja não produção nos lograria a todos, nem tampouco com um simples preenchimento do tempo em cena (...) (KenNer apud BeCKETT, 2005, p. 217, itálico meu).
\end{abstract}

"Não é uma fraude que Godot não venha" corresponde a dizer que é legítima sua ausência, ou ainda, que sua não vinda foi justamente construída ao longo de toda peça, mostrando sua necessidade. Novamente, a ideia de totalidade reaparece. Temos, assim, que a totalidade extensiva realiza negativamente a totalidade intensiva como proposta por Lukács em seu conceito.

\section{Nota sobre tipicidade e ação no(s) conceito(s) de realismo}

A ação é uma das categorias fundamentais para o conceito lukácsiano de realismo: ela aponta para uma noção ainda mais profunda e a qual o filósofo húngaro considerava muito importante: a noção de processo. A ação é o fator transformador tanto dos seres humanos quanto da sociedade. Mas existe aqui um aspecto suplementar e de primeira importância: para Lukács, a ação não era apenas necessária como fator representacional da realidade, senão, igualmente, possuía sua relevância para a técnica do escritor: a ação "empurra" os personagens aos dilemas e às decisões centrais de qualquer existência, fortalecendo, mesmo por cima dos conceitos e pré-conceitos do escritor, o sentido realista de sua obra ${ }^{2}$. Poder-se-ia mesmo dizer que, se para Lukács (que nisso coincide com Walter Benjamin) o realismo possui, como técnica, uma função organizadora ${ }^{3}$ de toda a literatura, a ação, por sua vez, é o fator organizador
[2] Tal ideia, presente em "Narrar ou descrever?", mas também em ensaios como "Marx e o problema da decadência ideológica", reforça a possibilidade, para Lukács, de que a objetividade da obra supere a subjetividade do escritor.

[3] De fato, tal ideia aparece em "O autor como produtor", de W. Benjamin: "Em outras palavras: seus produtos [do escritor], lado a lado com seu caráter de obras, devem ter antes de mais nada uma função organizadora (...).Um escritor que não ensina outros escritores não ensina ninguém" (Benjamin, 2010, p. 131). 
[4] Esta noção, parece-nos, é a mesma que, ao final da vida de Lukács, leva-o a encarar as mobilizações dos anos 1960 de maneira sensivelmente diversa daquela de Theodor Adorno, como exploraremos adiante: é a negação da sociedade de "administração total”, constitutiva já do seu conceito de realismo nos anos 1930. Nossa sugestão - que segue aqui Carlos Nelson Coutinho e Leandro Konder - é, portanto, a de que o realismo lukácsiano aposta, antes, na noção de possibilidade constante de ruptura do que (como afirmam alguns) no stalinismo como ruptura. do realismo. Importante mencionar também que, para o filósofo húngaro, o processo de transformação do personagem deve acompanhar o processo de transformação societal em radicalidade e complexidade: isto visa permitir que a expressão mais alta dos diversos traços humanos seja justificada pela singularidade radical das situações em que está inserida, sublinhando o que existe de tipicidade em determinado período histórico e evitando, assim, que o personagem passe por um simples excêntrico ou, ainda, uma monstruosidade inexplicável. Assim, observa Lukács:

\footnotetext{
A figuração de situações e de caracteres extremos somente se torna típica na medida em que, no conjunto da obra, fique claro que o comportamento extremo de um homem numa situação levada ao extremo exprime os mais profundos contrastes de um determinado complexo de problemas sociais (LuKÁCS, 2010, p. 196).
}

Vale ainda ressaltar que a noção de processo (mediada pela ação) corresponde, em Lukács, a uma força oposta ao sentido de imediaticidade do mundo. É dizer: destrói a visão de mundo "acabado" (que reina apenas na sua superfície, onde voga a ideologia), supostamente livre de conflitos fundamentais, e que atende, segundo ele, a um sentido conservador da realidade. É possível afirmar que, para Lukács, todo niilismo é sinal de decadência burguesa, na medida em que, enclausurando-se numa visão parcelar do mundo, recusa-se a ver a totalidade do processo social como de fato é: movimento constante de contradições, onde a possibilidade de ruptura e resistência nunca pode ser negligenciada ${ }^{4}$. Essa exposição, extremamente sucinta de um ponto extenso e complexo para Lukács, visa expor a categoria realista de ação (dividida em mobilidade e processo) perante a ideia, tão notada em Beckett, de inação (imobilidade e acabamento). Aqui, "acabamento" diz respeito a qualquer representação da realidade desvinculada de seus conflitos internos que são, ao final, o motivo de sua transformação constante, pelo que se justifica, reciprocamente, as noções de ação e de sujeito.

Para tentar esclarecer um pouco melhor o universo dentro do qual trabalhar-se-á o conceito de ação realista em Beckett, é necessário, antes de tudo, tentar precisar a que tipo de ação realista Beckett estaria filiado dentro do conceito lukácsiano. Isto se deve ao fato de que o conceito de realismo de Lukács não é, ao contrário do que pode se pensar, rígido, estático, unidimensional. Isto quer dizer o seguinte: nem toda obra realista é, segundo Lukács, uma obra progressista (inútil lembrar que o termo "progressista" se refere ao seu teor político inseparável de sua forma estética). Seguindo o conceito de realismo, poderíamos - contra o 
julgamento do próprio Lukács, sem dúvida - afirmar que a ação beckettiana não é uma ação realista na linha que provém de Balzac ou Tolstói, do grande realismo da fase heróica burguesa; mas, sim, filia-se melhor à linha que provém de um Flaubert ou de um Ibsen (sem, no entanto, chegar a um Zola, caracterizado como naturalista por Lukács), ou seja, é a ação do realismo decadente, ou rebaixado, do pós-1848. Existe aí a noção de gradação, portanto, do conceito de realismo.

O realismo de Flaubert é, ainda, aquele de um grande artista, como o considera Lukács. Madame Bovary e Educação Sentimental gozam, junto ao filósofo, de um elevado estatuto. Tanto essa grandeza quanto a noção de realismo flaubertiano decadente, que marca uma cesura em seu conceito de realismo (e, por conseguinte, na categoria de ação realista), estão presentes em toda a sua obra. A título de exemplo, no livro $O$ Romance Histórico, de 1936, Lukács diz:

A posição de Flaubert em relação à história conduz necessariamente - mesmo nesse grande estilista - a uma degradação da verdadeira forma da linguagem épica. O próprio Flaubert é um artista demasiado importante, um artista da linguagem demasiado grande para querer evocar a impressão de autenticidade histórica por meio de um tom coerentemente arcaizante. (LuKÁcs, 2011, p. 240)

Assim é que Flaubert, Ibsen e outros representam, no pensamento de Lukács, também um realismo onde, apesar da representação das profundas tensões sociais em jogo, é justamente a ação dos personagens que surge rebaixada, despotencializada, os seres alienados dos acontecimentos. Para ele, tal forma estética reflete a posição do artista que, após os massacres de 1848 e a aliança da burguesia vitoriosa à monarquia, já não vê o mundo como um espaço aberto à ação humana, tampouco movido pelos imperativos da razão e da liberdade reclamados por essa classe até então. A ideia de decadência provém exatamente desse estreitamento da consciência nos limites ideológicos da própria classe, e que não reconhece, portanto, no proletariado, o sujeito histórico coletivo cuja emancipação particular representa a emancipação do gênero humano. Para Lukács, no entanto, a grandeza desses artistas estava na sua coragem de representar honestamente tanto a decadência ideológica da burguesia quanto a sua própria angústia interior (aqui, a interioridade tem um lastro objetivo, sem cair no subjetivismo vazio das vanguardas do século vinte, como ele costumava encará-las) diante de um mundo em que as possibilidades de ruptura mais promissoras foram violentamente esmagadas. A repressão sobre a Primavera dos Povos não representou, 
numa perspectiva lukácsiana, somente a consolidação da burguesia, agora como força conservadora da história; para o artista, 1848 representou também a imposição de uma visão radicalmente crítica de seu próprio lugar dentro da sociedade burguesa: a sua impotência diante dos acontecimentos, mediada pela relação ambígua com a população desfavorecida, foi o fato objetivo central do rompimento do moderno com o romântico, em que a postura irônica diante do mundo ganha força. Cem anos mais tarde, contabilizadas a Comuna de Paris e duas guerras mundiais, Beckett escreve Esperando Godot. No tronco do realismo lukácsiano, seria justamente desse ramo do realismo decadente - ou "realismo crítico" - que a ação beckettiana se desenvolve.

\section{A CATEGORIA DE TIPICIDADE}

[Pozzo]: Quem são vocês?

[Vladimir]: Somos homens. (BECKETT, 2005, p. 165)

Para Adorno, assim como para Beckett, a experiência da Segunda Guerra Mundial ocupa lugar central em seu pensamento. Não é exagero dizer que a visão de mundo de ambos foi talhada, em grande medida, por essa experiência histórica tão avassaladora. Após o apocalipse, a catástrofe, esse grande Mal que se abateu sobre a Europa, os personagens de Samuel Beckett veem-se diante da necessidade de seguirem como animais gregários, atados ainda, portanto, a uma língua comum cuja eficácia está sensivelmente perdida, a uma forma de vida extrema que é uma sombra deformada da antiga existência, sobretudo temerosos de que o tempo não passe jamais ou que, esvaindo-se, a conta gotas, eles

[5] Uma maneira errada e vulgar de se pensar a tipicidade lukácsiana nesse contexto seria argumentar que, apesar de tudo, ainda subsistem, nas duas peças, papeis sociais como "patrão" e "empregado": fica claro que, onde eles não possuem sentido estruturante na obra, não são, de fato, tipicidades como pensou Lukács. Outra leitura mais comum (e de sentido mais filosófico do que sociológico) é a que busca lastrear em Beckett a dialética hegeliana do "senhor" e do "escravo" nas relações entre personagens. sejam arremessados outra vez na História, porém, sem memória nem razão suficientes que os previnam de danar-se outra vez. "Nunca ninguém pensou de modo tão tortuoso como nós", diz Clov, reverberando o sentido, constante em Beckett, de humanidade dilacerada. Tal radicalidade monstruosa das condições em que estão metidos os personagens - sem vislumbre de redenção, de saída - acaba por justificar a inação quase completa desses seres, todos distanciados de homens e mulheres que foram um dia. É através dessa lente que devemos olhar para a categoria de tipicidade lukácsiana na forma como ela aparece em Beckett: como uma categoria implodida. Já não se trata mais de um sujeito típico, porque pertencente a uma fração sócio-cultural historicamente determinada, senão de todo o gênero humano condensado no que resta de humanidade em Ham, ou em Vlad 5 . Como lembra Souza Andrade a respeito de Winnie, 
em Dias Felizes: "O significado de sua imobilidade progressiva, de sua memória esmorecente e de sua razão tortuosa é de outra ordem, mais vasta, que, mesmo expressa em termos e aflições femininas, atravessa a barreira dos gêneros" (ANDRADE, 2010, p. 12). Diversos são os momentos, na dramaturgia beckettiana, que ressaltam essa ideia. Ainda na mesma peça, ao apreciar as unhas recém feitas, Winnie comenta, mirando-as com atenção: "um pouco mais humana" (ВЕСКETT, 2010, p. 50). Igualmente, um simples pentear de cabelos ganha proporções compreensíveis apenas diante do cenário apocalíptico:

[Winnie]: (...) Meu cabelo! (Pausa.) Será que penteei e escovei meu cabelo? (Pausa.) Talvez sim. (Pausa.) Novamente eu me penteio. (Pausa.) Há tão poucas coisas a fazer. (Pausa.) E nós fazemos tudo. (Pausa.) Tudo que é possível. (Pausa.) É da natureza humana. (Começa a examinar a colina, levanta a cabeça.). Fraqueza humana (BECKETT, idem, p. 27).

Manter-se humano ou com romper com o que é considerado humano é constitutivo da tragédia pessoal de cada um dos personagens. Em tal situação, onde memória e inteligência se encontram consideravelmente arruinadas, toda e qualquer aparência adquire um relevo novo, essencializante, por assim dizer: parecer humano pode ser a barreira última dessa condição. No texto beckettiano, tal condição recebe não só seu quinhão de tragédia, mas, ao mesmo tempo, de sarcasmo. Esperando Godot é pródiga nesse aspecto:

[Estragon]: (Com vivacidade) Nós não somos daqui, meu senhor! [Pozzo]: (Estacando) Mas, ainda assim, são seres humanos. (Coloca os óculos.) Até onde se vê, pelo menos. (Tira os óculos.) Da mesma espécie que eu. (Explode em riso aberto.) Da mesma espécie que Pozzo. Feitos à imagem de Deus (BeCKETT, idem, p. 49).

Numa terra há muito abandonada por esse deus, a afirmação ressoa também o sentido da dominação, uma vez que Pozzo pode ser considerado, em Esperando Godot, o "deus de um servo só" (no caso, Lucky). Não se sabe muito bem, entretanto, se esse servo é de fato humano. Não se pode esquecer que, nessa peça, Lucky é aquele cuja faculdade de latir parece sensivelmente melhor do que aquela de pensar (o famoso monólogo sem sentido algum, quando a Lucky é ordenado que "pense!"). Na realidade, Lucky, por sua posição de subserviência - diversa daquela de camaradagem existente entre Vlad e Estragon, ou da posição de domi- 
nação, exercida por Pozzo -, parece sugerir que, num cenário desolado como esse, qualquer "passo atrás", qualquer "abaixar a cabeça" é o suficiente para chegar à animalidade. Essa é uma ameaça generalizada, causando desconfiança mesmo no mais arrogante dominador: "[Pozzo]: Ele (refere-se a Vladimir) não consegue mais suportar a minha presença. Talvez eu não seja particularmente humano" (BЕСKETT, idem, p. 58).

A favor dessa tipicidade implodida à maneira beckettiana, poder-se-ia afirmar também três coisas: 1. em uma situação de completa excepcionalidade, onde o apocalipse se tornou a verdadeira existência, nada pode ser excepcional. Ou, nas palavras de Winnie, em Dias Felizes: "Coisa estranha, numa hora dessas, lembrar de coisas assim. (Pausa.) Estranha? (Pausa.) Não, aqui tudo é estranho". 2. dada a relação intrínseca, para Lukács, entre ação e tipicidade, vale notar que a materialidade das situações em que se encontram imobilizados os personagens de Beckett impõem-se por sobre qualquer significado simbólico ou alegórico que se lhes deseje encontrar. Mesmo em Dias Felizes, onde poder-se-ia questionar a absurda situação de uma mulher enterrada até a cintura (e, no segundo ato, até o pescoço), Souza Andrade lembra que Winnie está presa "não a uma terra qualquer, mas a uma paisagem desértica, apocalíptica, em que a natureza se perverte e a atmosfera parece estar por um triz". Igualmente, em Esperando Godot, muitos são os sinais que apontam para a inutilidade de qualquer esforço para salvar-se do nada: um dos exemplos disso é quando Pozzo afirma que caminhou "seis horas a fio, sem encontrar vivalma". Esse mesmo cenário aparece ainda mais claro em Fim de Partida, onde o episódio da criança na praia fala por si. Ou seja, a inação em Beckett é de qualidade completamente diversa da inação, por exemplo, presente no nouveau roman francês da metade do século vinte. A diferença fundamental consiste em que, enquanto os seres do nouveau roman podem escolher, de uma maneira ou de outra, pela imobilidade; os seres beckettianos não têm opção: aqueles estão condenados à liberdade; estes, condenados ao cárcere. 3. por último, Beckett atualiza nessa tipicidade implodida a frase de Lukács sobre a teoria da alienação em Marx - de que "a burguesia possui somente a aparência de uma existência humana” (LuKÁcs, 2010, p. 70). O universo beckettiano é o locus revelador dessa aparência.

Com isso, deseja-se mostrar como a tipicidade, ao implodir, torna-se ela também extensiva porque problemática: já não está em jogo se Alexei Vronsky, em Anna Kariênina, atua como um verdadeiro oficial militar aristocrático ou se, digamos, Paulo Honório, em São Bernardo, à medida que ascende socialmente, atua coerentemente como um grande fazendeiro: trata-se de saber, isso sim, em que medida, diante do desespero e da catástrofe, um militar ou um fazendeiro podem agir como Vronsky 
ou como Honório, ou seja, como seres humanos. A tipicidade lukácsiana despe-se de seus "mantos sociais" - as questões de classe, ideologia e trajetória pessoal próprias dos personagens - não por força de um idealismo ingênuo (constata-se que "somos todos seres humanos"), um voluntarismo destemperado (as condições objetivas superadas pela obstinação), um subjetivismo irreprimido (a projeção do self para o mundo objetivo). Ao contrário, a tipicidade despe-se de seus "mantos sociais" para a dimensão do gênero humano porque este se torna, no universo beckettiano, a real dimensão do problema da tipicidade. Bertolt Brecht exprimiu isso da seguinte forma, falando do seu Sr. Keuner:

Quando o pensador se viu diante de uma grande tempestade, estava sentado num grande veículo e ocupava muito espaço. A primeira coisa que fez foi sair do veículo, a segunda foi tirar seu casacão. A terceira foi deitar-se no chão. Assim o pensador venceu a tempestade, reduzido a sua menor grandeza. Reduzido a sua menor grandeza, o pensador venceu a tempestade (BRECHT, 2006, p. 41).

Analogamente, em Beckett, a tipicidade lukácsiana aparece "reduzida a sua menor grandeza", o gênero humano, porque esta é a única maneira possível de vencer a tempestade que se abateu sobre aqueles que chegaram ao fim da partida. Assim, a categoria da tipicidade não se mantém às custas da anulação de todos os papeis sociais, mas, inversamente, somente por causa da anulação desses papeis. Com efeito, se se quisesse aferir a coerência dessa tipicidade, bastaria, num exercício de imaginação, tentar figurar Ham (em Fim de Partida) como um nobre rico, preocupado com seus lucrativos negócios, entretido com as desavenças ou querências familiares e tomado pelas obrigações advindas de sua abastada classe social: tudo isso diante de um cenário devastado pelo apocalipse. É justamente quando constatamos o quanto obras modernas figuram este tipo "absurdo" que podemos perceber, por contraste, a classicidade profunda de Beckett e a tipicidade coerente de seus personagens.

\section{A CATEGORIA DE $A C ̧ A ̃ O$}

É o que me dá forças para continuar, continuar falando, quero dizer (BЕCKETT, idem, p. 58)

Talvez a mais complexa a ser interpretada, a categoria de ação realista deve ser encarada à luz de tudo o que foi exposto até aqui: assim 
como a tipicidade, ela está resolvida, no universo beckettiano, da única maneira possível, apontada pelo próprio Adorno:

El gesto de quedarse quieto al final de Esperando Godot, la figura fundamental de toda su obra, reacciona con precisión a la situación [do Apocalipse]. Responde con violencia categórica. La plenitud del instante se convierte en la repetición sin fin, convergente con la nada. Sus relatos, que sardónicamente él llama de novelas (...), están igualmente marcados por la pérdida de objetividad motivada objetivamente y por su correlato, el empobrecimiento del sujeto (Adorno, idem, p. 48).

Porém, para mostrar como está resolvida a inação beckettiana dentro da ação realista de Lukács, é necessário ainda esclarecer como, em Beckett, surgem as duas dimensões (já citadas) dessa ação realista: o movimento e o processo. A ação realista em sua acepção primeira, de movimento, corresponde aqui às ações dos personagens, por meio das quais serão constituídas as transformações subjetivas e societais (ou seja, a segunda acepção, de processo). A primeira exigência, então, é constatar em que realidade estão inscritos os personagens beckettianos. Mencionou-se, até o momento, sua face apocalíptica, devastada, desértica. Vale, entretanto, explorar quais as implicações desse cenário na dramaturgia do irlandês:

La desproporción de la realidad con el sujeto despotenciado, que la hace completamente inconmensurable con la experiencia, le quita toda realidad. El surplus de la realidad es su ocaso; al matar al sujeto, se vuelve mortecina; esta transición es lo artístico en el antiarte. Beckett la impulsa hasta la manifiesta nihilización de la realidad. (...) Si se emplea todo lo laxamente posible el concepto de abstración, este indica la retirada del mundo de los objetos justamente allí donde no queda nada más que su caput mortuum. (ADoRNo, idem, p. 49).

A "retirada do mundo" significa aqui tanto a sua abstrusidade diante do indivíduo devido à incomensurabilidade (surplus) quanto, por implicação lógica, a eliminação desse mesmo indivíduo "despotenciado". Quando o filósofo afirma que "na intimização do que é grande se perde a contemplação da totalidade" (ADoRno, 1980, p 176), está recordando que a relação do indivíduo com o mundo somente pode se dar através de mediações múltiplas, sem as quais a compreensão da realidade (incomensurável) jamais pode ser efetivada. Tais mediações - testemunhas do percurso da consciência viva - são justamente o que surge ameaçado na obra de Beckett. O surplus do real é sua maneira de desaparecer, 
tornando-se inapreensível... Tragédia que já a sentira Franz Kafka pensamos, sobretudo, em O Processo (1925) - e cujas conseqüências para a (des)individuação relacionam diretamente seus romances com o trabalho do dramaturgo irlandês.

Daí advém a anulação da experiência, onde Adorno ressoa um tema caro igualmente a Walter Benjamin. Assim, esse mundo devastado e desértico é, para Adorno e Beckett, não somente aquele atingido pela bomba atômica, mas o mundo em que a bomba atômica tenha sido - como resultado de um processo de racionalização específico - concebida. Tal processo de racionalização, criticado por Adorno e Horkheimer desde Dialética do Esclarecimento, expressa-se na alienação do homem frente ao aparato tecnológico, construído para a dominação da natureza, e tornado absoluto. Na dialética adorniana, a afirmação total dessa realidade atua sobre o homem exatamente como a "perda da totalidade":

(...) Como muito frequentemente para Adorno, os conceitos fechados mudavam de sinal. A proeminência do objeto no sentido negativo significa a dominação das forças sociais tornadas autônomas sobre os indivíduos impotentes, estado da sociedade em que falta um sujeito da totalidade (WIGGERSHAUS, 2002, p.636-637).

Wiggershaus fala, ainda, dos "conjuntos funcionais sociais que haviam se tornado inacessíveis aos homens": reaparece o lastro kafkiano de Adorno e Beckett. Ao constatarmos assim que, na obra beckettiana, o mundo como tal está fora do alcance de seus habitantes, chegamos a uma situação em que a ação como movimento vê-se jogada contra a sua própria razão. A ausência deste vê-se equacionada em função de sua gratuidade. Sob este plano jaz a noção de "falência do indivíduo burguês", que para Adorno era a expressão de "pseudo-indivíduos pós-psicológicos no mundo administrado" (JAY, 1995, p. 85). Em Beckett, a mesma ideia está presente na própria estruturação da linguagem. Como diz Souza Andrade, "perceber e ser percebido, atributos com os quais o 'eu' se define, são postos em xeque. (...) A persistência da identidade do núcleo reflexivo não é mais um dado a priori, também ela está em questão" (ANDRADE, 2001, p. 20). Não por outro motivo, todo movimento em Beckett encontra-se refugiado naquilo que resta aos seres "despotenciados": na linguagem. Quando Adorno comenta sobre a historicidade imanente à obra beckettiana, ressalta-a do seguinte modo: "En el punto cero en que la prosa de Beckett funciona, como las fuerzas en lo infinitamente pequeño de la física, surge un segundo mundo de imágines (...), un concentrado de experiencias históricas" (Adorno, 2011, p.49). Esse "segundo mundo 
de imágines, un concentrado de experiencias históricas" que aparecem como "fuerzas en lo infinitamente pequeño de la física" está justamente nos diálogos intermináveis, repetidos sem ponto de fuga, que permeiam as relações entre os personagens.

A ação, em Beckett, está dada no âmbito microscópico, apenas visível diante do nada, do zero ou, em termos adornianos (a negatividade dessa mesma imagem), do surplus do real. O "infinitamente pequeno", nesse contexto, evoca a proporção tão bem expressa por Wallace Stevens em seu poema "Treze maneiras de olhar para um melro". A ação-movimento, refugiada (por assim dizer) dentro das palavras, tem justamente a força dessa única coisa movente "em vinte montanhas nevadas": não o melro, mas algo ainda menor, "o olho do melro". Comenta Souza Andrade: "Valendo-se das palavras (falhas) e das coisas (poucas) ao seu alcance, Winnie executa uma sequencia quebradiça de atos, constantemente interrompida, sem fim e sem finalidade". (ANDRADE, idem, p. 13). Ressalte-se aqui a relação direta das palavras como atos. Em outro trecho, o mesmo crítico diz: "No bálsamo das fórmulas recorrentes ('Ah! Hoje é um dia feliz!', 'Isso que eu acho maravilhoso.') e da incontinência verbal está a sua verdadeira mobilidade, mesmo que falha e frustrante" (ANDRADE, 2010, p. 20-21). Sentido semelhante está dado na fala de Winnie, utilizada aqui como epígrafe. "É o que me dá forças para continuar, continuar falando, quero dizer" (ВЕСKETT, idem, p. 37). Chama a atenção, nesse trecho, o fato de que o verbo "falando" ocupa o lugar normalmente reservado ao verbo "vivendo", o que demonstra o real estatuto da palavra para esses seres tolhidos em seus esforços mais débeis. Com a função de auxiliar na travessia do dia, as palavras assumem um papel fundamental. "As palavras faltam, há momentos em que até mesmo elas nos faltam" (BECKETT, idem, p. 38-39). Assim, a linguagem dos personagens não é a re-experiência de uma ação ocorrida no passado ou sequer a preparação para uma ação futura; tampouco é sublimação discursiva dessa ação tornada inviável, marcada conseqüentemente por um ressentimento profundo: nada disso está no texto beckettiano. Em Beckett, a linguagem (as falas dos personagens) surge como uma ação-movimento negativa exatamente porque se apresenta como a expressão da ausência desta, demonstrando a consciência de sua impossibilidade pós-apocalipse, mas sem desejar sublimá-la (por exemplo, carpindo-a). O "ponto zero" da linguagem surge resolvido numa intrincada construção cujo sustentáculo é sua própria dinâmica interior, seu jogo dialético de tensões resolvido em si. Para usar a imagem recuperada por Antonio Candido em Literatura e Sociedade: a linguagem aparece como aquele Barão de Münchhausen que, para escapar à morte, arrancou-se do pântano puxando-se pelos próprios cabelos. Este trabalho 
dialético interior é notado por Terry Eagleton, em seu comentário sobre o estilo modernista comum a Beckett e Adorno:

Beckett's is a life devoted to silence, exile and cunning. Adorno's style reveals a similar austerity, as each phrase is forced to work overtime to earn its keep, each sentence wrought into a little miracle or masterpiece of dialectics. (...) It is a distinctively Modernist style, in which the truth can no longer be portrayed directly but can only be squinted at out of the corner of one's eye, grasped only by bouncing one proposition against its opposite. Perhaps this is what Adorno had in mind when he called art a negative image of reality. (EAGLETON, acessado em 2015)

Eagleton aponta, assim, para outro fator em comum, além de certa visão apocalíptica do mundo: o fato (recorrente nessa análise) de que a ideia de negatividade é central, seja para a dialética adorniana, seja para os caminhos explorados por Samuel Beckett em sua tentativa de superar a forma do drama burguês. Fazendo coro com essa ideia do negativo, diz Günther Anders sobre a relação movimento e linguagem:

[Beckett] destrói tanto a forma quanto o princípio até então característicos das fábulas: agora a fábula destruída, a fábula que não mais segue adiante, torna-se a representação adequada da vida estagnada (...). Se ela renuncia a relatar uma ação, o faz apenas porque a ação que descreve é a vida desprovida de ação. Se desafia a convenção ao não oferecer história alguma, o faz por descrever o homem eliminado da, e desprovido de, história. (...) Ainda que se trate de uma, por assim dizer, fábula negativa, continua sendo uma fábula (in: ВЕСKETT, 2005, p. 214).

Esta impossibilidade de seguir adiante (e, no entanto, continuar seguindo) é o que dá à/exige da palavra seu efeito análogo àquele do movimento, do ato, qual seja: a capacidade transformativa do mundo. A ação, aqui, tampouco é a ação que gera uma mudança radical. Assim como a "verdade" que não pode mais ser "olhada de frente" (Eagleton sobre Beckett e Adorno), também a ação só é "agarrada quando jogando uma proposição contra a sua oposição". Esse é todo o trabalho da linguagem beckettiana. As palavras são ações no sentido em que também criam um pequeno universo. Como quando Winnie cria um Sr. ou Sra. Shower ("ou Cooker"):

(...) Me vem a imagem - caída das nuvens - de um Sr. Shower - um Sr. e talvez uma Sra. Shower - não - estão de mãos dadas - deve 
ser sua noiva - ou só uma namorada - nova (...). Shower - Shower (...) - esse nome lembra alguma coisa - lembra Willie - evoca alguma lembrança - uma realidade qualquer, quero dizer (...). Shower - ou Cooker - termina em 'er' - tenho certeza - diz: O que significa isso? O que será que ela pensa que isso significa? - e patati patatá - muito mais coisa do tipo - a bobageira de sempre (...) (BECKETT, idem, p. 49).

Em Esperando Godot, por sua vez, Vladimir e Estragon constroem um espetáculo de circo a partir (sem dúvida, sem exageros) do pó:

[Vladimir]: Tarde maravilhosa.

[Estragon]: Inesquecível.

[Vladimir]: E ainda nem acabou.

[Estragon]: Parece que não.

[Vladimir]: Mal começou.

[Estragon]: É sofrível.

[Vladimir]: Pior que um espetáculo.

[Estragon]: De circo.

[Vladimir]: De pantomima.

[Estragon]: De circo.

[Pozzo]: Mas onde diabos enfiei meu pito?

[Estragon]: Divertido, ele! Agora perdeu a chaminé (Riso ruidoso)

[Vladimir]: Já volto (Vai em direção à coxia)

[Estragon]: No fundo do corredor, à esquerda.

[Vladimir]: Guarde meu lugar. (Sai) (ВеСКетт, 2005, p. 69-70).

Em passagens como essas, as palavras parecem assumir as potencialidades físicas da ação. É na oposição entre um presente miserável (porém, honesto) e um passado abastado (porém, falso) onde reside também a subcategoria de processo, como complemento da categoria de ação realista. Como dito, a ideia de processo, para Lukács, tem importância justamente porque se coloca contra a imagem de mundo acabado, isento de transformações profundas. Tal noção de processo também é problemática nas três peças analisadas, visto que nelas o passado aparece sempre apartado do presente por um corte abrupto, sem solução de continuidade. Todos os personagens citam o tempo pregresso como uma vida qualitativamente estranha à atual, sem, no entanto, romper completamente com a causalidade. Ela - a razão desconhecida da miséria atual - é mais fielmente obscurecida, colocada à sombra, como um tabu ou um fato que, por tão notório, dispensa qualquer comentário. "A única oposição forte se dá com um 'antigamente', tempo remoto, perdido nos 
primórdios da humanidade, quando "éramos gente distinta"' (ANDRADE, 2005, p. 11). Na verdade, esse tempo pregresso, de vida qualitativamente diversa, mistura-se frequentemente a uma ideia de tempo mítico, onde toda existência é radicalmente outra. Na sequencia reproduzida abaixo, vê-se primeiro a ideia de um tempo mítico (cuja referência é o pecado original cristão), e, em seguida, a ideia de um tempo pregresso em vida:

[Vladimir]: E se nos arrependêssemos?

[Estragon]: Do quê?

[Vladimir]: Ahnnn... (Reflete) Não precisamos entrar em detalhes.

[Estragon]: De termos nascido? (...)

[Vladimir]: Lembra dos Evangelhos?

[Estragon]: Lembro dos mapas da Terra Santa. Coloridos. Bem bonitos. Mar Morto de um azul bem claro. Dava sede só de olhar. É para lá que vamos, eu dizia, é para lá que vamos na lua-de-mel. E como nadaremos. E como seremos felizes.

[Vladimir]: Você devia ter sido poeta.

[Estragon]: E fui. (Indicando os farrapos com um gesto) Não está na cara? (BECKETT, idem, p. 22-23).

Que o fato de mirar o mapa da Terra Santa seja coroado com a resolução - tão trivial quanto irônica - "é para lá que vamos na lua-de-mel" contém, em si, a síntese desse encontro entre o tempo humano e o tempo mítico. Na utilização de um e de outro fica clara a noção de que a vida foi interrompida. É como se, uma vez na História, os personagens houvessem sido arrojados para fora do tempo por essa ideia de catástrofe que permeia todas as peças do dramaturgo irlandês. $\mathrm{O}$ tempo mítico ressurge para assombrar o tempo presente, opondo a ele a sua imagem cíclica que afasta, por isso mesmo, a noção de liberdade humana, que para Adorno está relacionada à vida política. Ainda assim, algo de mudança subsiste, ainda que sob o signo da decadência. "De resto, os fragmentos que Winnie evoca ao longo da peça (explicitamente ou não) são um forte indício de que sua memória está degringolando. De Shakespeare e Milton ela desce a autores cada vez menores, recortados a partir de sua perspectiva restrita" (ANDRADE, 2010, p. 20). No mundo pós-apocalíptico, "as personagens (...) estão às voltas com a tarefa de acabar de existir, virtualmente infinita e de conclusão impossível” (ANDRADE, idem, p. 14). Dessa forma, o que fica claro é que não se trata, novamente, da representação de um mundo burguês, onde as forças sociais em jogo - tão caras a Lukács - estão simplesmente ignoradas, como se o processo social (a luta de classes) houvesse cessado. "Os homens do mundo real não agem um 
ao lado do outro, mas um em favor do outro ou contra o outro; esta luta é o fundamento da existência e do desenvolvimento da individualidade humana" (LuKÁCS, idem, p. 191). Pelo contrário, a dramaturgia beckettiana se faz (como demonstrado com categorias anteriores) pela necessária reconfiguração completa desse mundo. Nele, a sociedade burguesa jamais aparece como uma realidade finda em si, senão como a sociedade que precedeu a (e levou à) própria catástrofe. É assim que o mundo desolado de Beckett surge: se não como a expressão mais radical da sociedade burguesa (a experiência da Segunda Guerra Mundial, do nazismo, dos campos de concentração, etc.), ao menos como um prenúncio ao revés dos desígnios dessa sociedade. Para Adorno, por sua vez, tal universo era a própria experiência do mundo burguês. Tratando, afinal, dos romances de Beckett, ele afirma: "estas novelas dan con capas [camadas] fundamentales de la experiência hic et nunc y las detienen en una dinámica paradójica" (Adorno, idem, p. 48). Aqui, o julgamento de Adorno corrobora a afirmação lukácsiana (citada acima) de que "a burguesia possui somente a aparência de uma existência humana".

Constata-se que a categoria de ação-processo, quando analisada dentro da obra de Samuel Beckett, mantém-se, bem como outras abordadas até aqui, plenamente adequada à perspectiva da realidade esboçada. É, portanto, sobre essa perspectiva que, acreditamos, repousam as verdadeiras e importantes divergências entre o conceito de realismo lukácsiano e algumas das principais peças de Samuel Beckett. O que buscamos fazer neste texto foi explorar as categorias internas ao conceito de realismo de Lukács, jogando-as contra a escrita de Beckett e com o auxílio - à primeira vista improvável - de Theodor Adorno. Implodir algo da modernidade beckettiana com as categorias realistas de Lukács, e implodir algo do conceito de realismo com as formas modernas da dramaturgia de Samuel Beckett constituíam parte dos objetivos.

Para tanto, vimos que a noção de totalidade se mantém em Beckett na sua forma extensiva, realizando pela necessidade a mesma função que Lukács (e leitores como Leandro Konder) predicam à mesma no romance, já aqui sob a chave da intensidade. Em seguida, uma breve análise da categoria de tipicidade - uma tipicidade "implodida", despida de seus papeis sociais pelo advento do apocalipse - nos conduziu à distinção da categoria de ação em duas: 1. ação-movimento, 2. ação-processo.

Com papel assegurado na construção da tendência realista da própria obra, a ação-movimento surge em Beckett na linha de certo realismo decadente ou crítico (com o qual se relacionaria Gustave Flaubert no pós-1848), onde seu estatuto apenas sobrevive em caráter de rebaixamento. Este rebaixamento, em última instância, recairia sobre a própria 
linguagem do dramaturgo que, não sendo re-experiência nem sublimação, brilha como o extremamente pequeno, por onde ainda se buscaria uma saída à dignidade humana. Por sua vez, a ação como processo se encontraria cindida, nas três peças analisadas, entre um tempo mítico e um tempo presente. Se o tempo mítico, no seu caráter cíclico, vem recordar a inutilidade de toda existência atual, por seu turno o tempo presente testemunha as criaturas "às voltas com a tarefa de acabar de existir", tarefa à qual somente esse "pequeno milagre da dialética" - nas palavras de Terry Eagleton - pode oferecer um sentido. I 


\section{REFERÊNCIAS BIBLIOGRÁFICAS}

ADORNO, Theodor. Teoría Estética. Madrid: Ediciones Akal, 2011.

Filosofia da Nova Música. São Paulo: Editora Perspectiva, 2007.

"O fetichismo na música e a regressão da audição". In: Os Pensadores. São Paulo: Abril Cultural, 1980.

ANDRADE, Fábio de Souza. "Matando o tempo: o impasse e a espera". In: Beckett, Samuel. Fim de Partida. São Paulo: Cosac Naify, 2002.

“Prefácio”. In: Beckett, Samuel. Esperando Godot. São Paulo: Cosac Naify, 2005.

"A felicidade desidratada”. In: Beckett, Samuel. Dias Felizes. São Paulo: Cosac Naify, 2010.

. O Silêncio Possível. São Paulo: Ateliê Editorial, 2001.

BECKETT, Samuel. Fim de Partida. São Paulo: Cosac Naify, 2002.

Esperando Godot. São Paulo: Cosac Naify, 2005

Dias Felizes. São Paulo: Cosac Naify, 2010.

BENJAMIN, Walter. Obras Escolhidas - Magia e Técnica, Arte e Política. São Paulo: Editora Brasiliense, 2010.

BRECHT, Bertolt. Histórias do Sr. Keuner. São Paulo: Editora 34, 2006.

EAGLETON, Terry. Determinacy Kills. In: http://www.Irb.co.uk/v30/n12/terryeagleton/determinacy-kills. Acessado em 7 de agosto de 2015.

KONDER, Leandro. As artes da palavra - Elementos para uma poética marxista. São Paulo: Boitempo Editorial, 2005.

LUKÁCS, György. Marxismo e Teoria da Literatura. São Paulo: Expressão Popular, 2010.

O Romance Histórico. São Paulo: Boitempo Editorial, 2011. 
. Realismo Crítico Hoje. Brasília: Coordenada Editora, 1969.

STEVENS, Wallace. Thirteen Ways of Looking at a Blackbird.

In: http://www.germinaliteratura.com.br/wstevens.htm. Acessado em 2 de outubro de 2015.

TERTULIAN, Nicolas. Lukács/Adorno: a reconciliação impossível. In: Revista Verinotio - Revista on-line de educação e ciências humanas, n. 11, 2010. In: http://www.verinotio.org/conteudo/0.49958592234141.pdf. Acessado em 2 de outubro de 2015.

WIGGERSHAUS, Rolf. A Escola de Frankfurt - História, desenvolvimento teórico, significação política. Rio de Janeiro: Editora Bertrand Brasil, 2002. 